\title{
Strategi Keberdayaan Masyarakat Menuju Desa Wisata Berbasis Masyarakat Yang Berkelanjutan
}

\author{
Irwan', Andi Agustang ${ }^{2}$ \\ Universitas Negeri Makassar \\ Email: Irwanunsa212@gmail.com
}

\begin{abstract}
Abstrak. Penelitian ini bertujuan menganalisis strategi transformasi konsep pemberdayaan masyarakat menjadi konsep keberdayaan masyarakat di daerah objek wisata dan menganalisis potensi sumber daya sosial serta sumber daya objek penelitian untuk menjadi desa wisata berbasis masyarakat yang berkelanjutan. Penelitian ini dilaksanakan di objek wisata Panrangluhung, Desa Bira, Kecamatan Bonto Bahari, Kabupaten Bulukumba. Metode penelitian yang digunakan adalah qualitative jenis studi kasus. Informan penelitian ditentukan secara purposive yang terdiri dari kepala desa, Badan Perwakilan Desa (BPD), tokoh masyarakat, pemuka agama, tokoh perempuan, tokoh pemuda, masyarakat desa, aparat pemerintah kecamatan dan aparat Dinas Pariwisata Kabupaten. Data dianalisis dengan menggunakan analisis data kualitatif. Hasil penelitian menunjukkan bahwa masyarakat belum merasakan dampak ekonomi secara langsung terhadap keberadaan objek wisata tersebut. Meskipun demikian, masyarakat mengaku bersedia melibatkan diri untuk memajukan pariwisata di daerah mereka. Data menunjukkan bahwa pengembangan objek wisata berbasis masyarakat belum menjadi prioritas di lokasi penelitian. Namun, Pemerintah Desa Bira menunjukkan keterbukaan dan kesediaan melakukan transformasi desa dari objek wisata menjadi desa wisata berbasis masyarakat yang berkelanjutan. Strategi transformasi yang dapat dilakukan adalah melakukan social mapping untuk mengungkapkan potensi sosial, termasuk nilai, norma, adat istiadat dan potensi sumber daya alam. Berdasarkan potensi tersebut, dilakukan desiminasi potensi kepada para pihak terkait. Selanjutnya, dihadirkan fasilitator desa wisata mandiri, yang bisa berasal dari luar desa jika belum ada fasilitator dari dalam desa. Berdasarkan data dapat disimpulan bahwa penelitian ini mengeritik model pemberdayaan yang selama ini berlangsung di Desa Bira dan menawarkan model keberdayaan masyarakat. Data menunjukkan bahwa model keberdayaan masyarakat dapat diimplementasikan di desa ini untuk mendukung terwujudkan Desa Bira sebagai Desa Wisata Berbasis Masyarakat Berkelanjutan (SRCBT). Konsep ini adalah integrasi konsep desa wisata, pariwisata berbasis masyarakat dan pariwisata berkelanjutan dalam satu batasan Desa Wisata Berbasis Masyarakat Berkelanjutan (Sustainable Rural Community Based Tourism). Penelitian ini juga melengkapi konsep elemen desa wisata, yaitu kesediaan masyarakat setempat untuk menjadikan daerah mereka sebagai desa wisata dimana hal ini tidak dibahas dalam konsep desa wisata.
\end{abstract}

Kata Kunci: Panrangluhung, Desa Bira, Pemberdayaan Masyarakat, Keberdayaan Masyarakat, Transformasi, Sumber Daya Sosial, Pemetaan Sosial, Fasilitator, Desa Wisata Berkelanjutan 


\section{PENDAHULUAN}

Sektor pariwisata merupakan industri terbesar dunia yang paling banyak menyerap tenaga kerja. Sektor ini tidak hanya melibatkan pengusaha bermodal besar tapi justru melibatkan banyak usaha kecil. Seperti dirumuskan The ASEAN Secertariat (2016) bahwa secara internasional, sektor ekonomi pariwisata didominasi oleh usaha kecil yang menyediakan barang dan jasa untuk pelanggan wisata yang berkunjung (Arifin dan Arifin, 2020). Dengan demikian, pariwisata memiliki potensi besar menumbuhkan kesejahteraan masyarakat sekitar objek wisata. Hal ini sejalan dengan Undang-Undang Republik Indonesia Nomor 10 Tahun 2009 Tentang Kepariwisataan,

khususnya Pasal 4 bahwa kepariwisataan bertujuan untuk; (a) meningkatkan pertumbuhan ekonomi; (b) meningkatkan kesejahteraan rakyat; dan (b) menghapus kemiskinan; mengatasi pengangguran. Hal ini menunjukkan bahwa pariwisata telah diyakini sebagai salah sektor utama yang menjadi andalan untuk kesejahteraan rakyat.

Terkait dengan agenda global Sustainable Development Goals (SDGs), trend

pariwisata bergeser ke arah pelibatan masyarakat setempat sebagai pemangku kepentingan utama dalam pariwisata. Hal ini dibuktikan dengan pengembangan dan implementasi konsep Community Based Tourism (CBT) oleh ASEAN Secretariat (2016) dan organisasi dunia seperti Asia-Pacific Economic Cooperation (APEC) menegaskan sustainable tourism (pariwisata berkelanjutan). Pada dasarnya, dua organisasi dunia tersebut menekankan pentingnya pelibatan masyarakat setempat dalam kepariwisataan. Sehingga masyarakat setempat tidak menjadi "penonton" di tanah leluhur mereka sendiri.

Salah satu objek wisata yang popular di Provinsi Sulawesi Selatan adalah Bira atau Desa Bira, Kecamatan Bonto Bahari, Kabupaten Bulukumba. Berdasarkan penelitian Musawantoro dan Ridwan (2019), salah satu objek yang memiliki potensi besar di desa ini adalah Pantai Panrangluhung. Menurut hasil penelitian ini, Pantai Panrangluhung memiliki daya tarik berupa pasir putih, panorama dan aktivitas pembuatan phinisi dan koneksitas antara objek wisata di Desa Bira sudah saling terhubung. Beberapa objek wisata di Desa Bira selain Pantai Panrangluhung, antara lain; makam Pua Janggo Makam Dato Tiro, Permandian Hila-hila Pantai Lolisang dan Pantai Samboang.

Data juga menunjukkan bahwa meskipun Desa Bira telah menjadi objek wisata populer di Sulawesi Selatan namun eksistensi desa ini sebagai objek wisat belum mampu meningkatkan taraf kesejahteraan masyarakat desa, khususnya masyarakat di sekitar Pantai Panrangluhung secara menyeluruh. Hal ini dapat dilihat dari jumlah keluarga miskin di daerah ini. Berdasarkan data BPS Bulukumba (2020), jumlah penduduk Desa Bira sebanyak 3.585 jiwa dengan rincian, penduduk laki-laki berjumlah 1560 dan perempuan berjumlah 2025. Data menunjukkan bahwa jumlah penduduk miskin di Desa Bira sebanyak 760 jiwa atau sekitar $21 \%$ dari total penduduk. Data ini menunjukkan bahwa keberadaan Desa Bira sebagai objek wisata belum mampu meningkatkan kesejahteraan masyarakat secara merata. Hal ini dibuktikan dengan masih tingginya jumlah penduduk miskin di desa tersebut. 
Fenomena di Desa Bira di atas, secara sosiologis, menunjukkan bahwa terdapat hal penting yang diabaikan, yaitu pelibatan dan pemberdayaan masyarakat setempat dalam keberlangsungan pariwisata di desa ini. Melalui website resmi Desa Bira, yaitu; www.desabira.com, diketahui bahwa Pemerintah Desa Bira telah membentuk Kelompok Kerja pembangunan berkelanjutan (Pokja SDGs). Namun, pelibatan masyarakat desa belum terwujud dalam bentuk pemberdayaan yang berkelanjutan.

Selain itu, dalam konteks pariwisata, berdasarkan Laporan Realisasi Pelaksanaan Anggaran Pendapatan dan Belanja Desa (APBD Desa Bira) tahun 2020, program pencanangan Desa Bira sebagai desa wisata berbasis Community Based Tourism (CBT) dan Sustainable Rural Tourism (Desa Wisata Berkelanjutan) belum terlihat. Programprogram yang dilaksanakan masih bersifat seremonial dan tidak bersifat khusus. Oleh karena itu penting dilakukan pemberdayaan masyarakat untuk melibatkan masyarakat setempat, khususnya komunitas masyarakat di sekitar Pantai Panrangluhung guna mendorong implementasi desa wisata berbasis masyarakat.

Tentu saja konsep pemberdayaan dimaksud adalah konsep pemberdayaan yang benar-benar bersumber dari pengetahuan, keterampilan dan kearifan masyarakat setempat untuk kemudian diimplementasikan berdasarkan kebutuhan masyarakat setempat dan pengunjung yang datang ke daerah ini. Potensi Desa Bira, khususnya masyarakat di sekitar Pantai Panrangluhung, untuk menerapkan konsep Sustainable Rural Community Based Tourism (SRCBT) sangat besar. Sehingga keberlangsungan pariwisata dapat menjadi bagian integral dari kehidupan masyarakat. Tentu saja dengan konsep penguatan bersama (keberdayaan) yang mengintegrasikan ilmu pengetahuan, keterampilan, kearifan masyarakat setempat dengan masyarakat dari luar yang seimbang dalam mengelola keseluruhan potensi wisata menjadi pendukung terwujudnya Desa Bira sebagai Desa Wisata Berbasis Masyarakat yang Berkelanjutan atau Sustainable Rural Community Based Tourism (SRCBT).

Oleh karena itu, konsep keberdayaan masyarakat yang terintegrasi dengan konsep SRCBT penting menjadi kajian ilmiah untuk mendorong peningkatan kesejahteraan masyarakat setempat. Dengan demikian, bukan hanya masyarakat setempat yang mendapat benefit dari penelitian ini, tapi secara akademik, terdapat kontribusi signifikan terhadap mengembangan konsep-konsep pembedayaan masyarakat dan konsep Sustainable Rural Community Based Tourism (SRCBT) atau Desa Wisata Berbasis Masyarakat yang Bekelanjutan sebagai agenda pembangunan global.

\section{BAHAN DAN METODE}

Penelitian ini dilaksanakan di objek wisata Panrangluhung, Desa Bira, Kecamatan Bonto Bahari, Kabupaten Bulukumba pada Maret 2021. Metode penelitian yang digunakan adalah qualitative jenis studi kasus (Andi Agustang, 2011) dan (Andi Agustang, 2021). Informan penelitian ditentukan secara purposive yang terdiri dari kepala desa, Badan Perwakilan Desa (BPD), tokoh masyarakat, pemuka agama, tokoh perempuan, tokoh pemuda, masyarakat desa, 
aparat pemerintah kecamatan dan aparat Dinas Pariwisata Kabupaten. Data primer dikumpulkan melalui wawancara mendalam dan data sekunder melalui kajian literatur dan dokumen-dokumen terkait, baik secara daring maupun luring. Data dianalisis dengan menggunakan analisis data kualitatif, yaitu; display data, kategorisasi data dan penarikan kesimpulan (Andi Agustang, 2015)

\section{HASIL DAN PEMBAHASAN}

Hasil penelitian menunjukkan bahwa masyarakat belum merasakan dampak ekonomi secara langsung terhadap keberadaan Desa Bira sebagai objek wisata. Keberadaan hotel, penginapan, sarana dan prasarana wisata lainnya di Desa Bira masih didominasi oleh kelompok pemilik modal. Bahkan, masyarakat di lokasi penelitian, Pantai Panrangluhung, mengaku belum memahami model pemberdayaan, termasuk pemberdayaan bidang pariwisata. Hal ini menunjukkan bahwa masih terjadi jarak sosial (social distancing) yang jauh antara masyarakat setempat dan kepariwisataan.

Data juga menunjukkan bahwa konsep-konsep pemberdayaan masyarakat telah diimplemetasaikan di Desa Bira. Program dan kegiatan pemberdayaan masyarakat dilakukan oleh pemerintah. Berdasarkan data informan, model pemberdayaan dilakukan melalui pelaksanaan pelatihan-pelatihan yang menghadirkan nara sumber dari Kabupaten Bulukumba. Selain itu, juga terdapat petugas pendamping desa yang ditugaskan oleh pemerintah. Meskipun demikian, data menunjukkan bahwa konsep pemberdayaan yang dilakukan selama ini masih menekankan pentingnya kehadiran narasumber dan atau sumber daya dari luar desa. Sementara eksplorasi, pemetaan dan pelibatan sumber daya masyarakat setempat belum dilakukan. Hal ini menyebabkan terjadinya ketergantungan masyarakat setempat terhadap keberadaan pendamping dan nara sumber dari luar. Sehingga, keberadaan program-program intervensi tersebut sulit menjadi program berkelanjutan.

Intervensi program pemberdayaan dari luar belum bersifat khusus untuk mendukung kepariwisataan Desa Bira, khususnya, Desa Bira sebagai Desa Wisata Berbasis Masyarakat Berkelanjutan (DWBMB). Salah satu penghambat agenda ini adalah tidak adanya data sosial yang berbasis masyarakat, yaitu data yang dihasilkan dari pemetaan sosial (social mapping) berdasarkan potensi sosial rumah tangga. Data yang tersedia bersifat makro yang digunakan untuk mengintervensi program kesejahteraan seperti bantuan sosial dan pembangunan infrastruktur desa.

Berkaitan dengan program prioritas pembangunan Desa Bira, data menunjukkan bahwa pengembangan objek wisata berbasis masyarakat belum menjadi prioritas. Namun, Pemerintah Desa Bira menunjukkan keterbukaan dan kesediaan melakukan transformasi desa dari objek wisata menjadi DWBMB. 


\section{Potensi dan Peluang Transformasi Model "Pemberdayaan" Menjadi "Keberdayaan"}

Konsep pemberdayaan bertujuan untuk meningkatkan keberdayaan dari mereka yang dirugikan. Strategi pemberdayaan dapat dilakukan melalui kebijakan dan perencanaan; aksi sosial dan politik; dan pendidikan dan penyadar-tahuan (Ife dan Tesoriero, 2008). Pembedayaan melalui kebijakan dan perencanaan dapat dicapai dengan mengubah struktur-struktur dan atau lembaga-lembaga untuk membuka akses yang lebih adil kepada sumber daya atau berbagai layanan dan kesempatan untuk berpartisipasi dalam kehidupan masyarakat. Pemberdayaan melalui aksi sosial dan politik menekankan pentingnya perjuangan dan perubahan politik dalam meningkatkan kekuasaan yang efektif. Pemberdayaan melalui pendidikan dan penyadar-tahuan menekankan pentingnya proses edukatif untuk meningkatkan keberdayaan mereka. Konteks "keberdayaan" menurut (Ife dan Tesoriero, 2008) adalah hasil dari pemberdayaan (empowerment). Konsep-konsep ini menekankan adanya pengetahuan dari luar untuk menguatkan masyarakat setempat, termasuk memasukkan "kosa kata" baru untuk menguatkan masyarakat. Konsep ini berdampak pada intervensi program dari luar dan "orang hebat" dari luar masyarakat yang "seolah-olah" memahami secara pasti kondisi sosial, ekonomi, budaya dan lingkungan masyarakat setempat. Praktek pemberdayaan seperti ini justru menempatkan masyarakat setempat sebagai orang yang harus diajar dan atau diberdayakan oleh kekuatan dari luar.

Demikiam halnya dengan konsep pemberdayaan berdasarkan Peraturan Menteri Kebudayaan dan Pariwisata Nomor: PM.26/UM.001/MKP/2010 tahun 2010 tentang Pedoman Umum Program Nasional Pemberdayaan Masyarakat (PNPM) Mandiri Pariwisata Melalui Desa Wisata. Menurut regulasi ini, yang dimaksud pemberdayaan masyarakat adalah menciptakan atau meningkatkan kapasitas masyarakat, baik secara individu maupun berkelompok, dalam memecahkan berbagai persoalan terkait upaya peningkatan kualitas hidup, kemandirian dan kesejahteraannya. Baik konsep yang dikemukakan Ife dan Tesoriero (2008) maupun regulasi di atas tidak menegaskan urgensi kekuatan dari dalam masyarakat sendiri namun menegaskan adanya kekuatan dari luar untuk menguatkan (empower) masyarakat. Padahal, konsep pemberdayaan sejatinya lebih menekankan pendayagunaan potensi dan kakuatan dari dalam masyarakat sendiri karena masyarakat setempat memiliki pengetahuan, keterampilan, nilai, norma dan kearifankearifan yang justru lebih memahami kondisi sosial, ekonomi dan budaya mereka. Intervensi dari luar, paling tidak, seimbang dengan sumber daya dari dalam. Konsep inilah yang disebut konsep "keberdayaan" atau (in-powerment) dan bukan (empowerment). Gagasan ini menunjukkan perbedaan dengan konsep yang dikemukakan Ife dan Tesoriero (2008) dan (Rajab et al., 2021).

Tranformasi atau perubahan konsep pemberdayaan (empowerment) memanjadi konsep keberdayaan (in-powerment) berdasar pada data informan yang mengemukakan bahwa terdapat beberapa sumber daya sosial yang telah dimiliki 
masyarakat setempat, seperti adanya anggota masyarakat yang telah menyelesaikan pendidikan tinggi, juga terjadi transformasi pengetahuan dari luar karena adanya anggota masyarakat setempat yang merantau dan memiliki pengalaman, terdapat keterampilan khusus masyarakat setempat dalam membuat perahu finisi, anggota masyarakat dapat aneka penganan. Selain itu, berdasarkan data, informan bersikap terbuka dan ramah serta bersedia menjadikan sebagian kamar rumah mereka sebagai tempat menginap tamu yang datang ke daerah mereka. Yang tidak kalah pentingnya, mereka bersedia membuka diri untuk belajar dan berpartisipasi dalam mengembangkan daerah mereka menjadi model desa wisata berbasis masyarakat berkelanjutan jika mereka diajak atau diberi kesempatan.

Informan menegaskan bahwa mereka bersedia belajar keluar daerah untuk memperoleh pengetahuan tentang desa wisata. Mereka mengaku lebih memilih untuk keluar belajar untuk melihat langsung desa wisata yang sudah berhasil dibandingkan jika mereka diceramahi. Informan mengatakan bahwa jika mereka dilatih atau diceramahi maka pengetahuan mereka terbatas tapi jika mereka menyaksikan langsung ke daerah desa wisata yang sudah berhasil maka mereka memili pengetahuan yang lebih banyak. Setelah ini, informan mengaku bahwa mereka bersedia menerapkan model desa wisata di daerah mereka setelah mereka memiliki pengeahuan dari luar. Alasannya, praktek-praktek desa wisata yang akan mereka lakukan tetap berkelanjutan karena mereka adalah masyarakat yang memang menetap di daerah tersebut. Meskipun demikian, infprman juga menyadari bahwa pelatih atau fasilitator desa wisata dari luar juga penting jika memang mereka tidak memiliki kemampuan finansial untuk melihat langsung desa wisata yang telah berhasil di daerah lain.

Beberapa langkah strategis yang dapat dilakukan atas persetujuan informan adalah; informan bersedia melibatkan diri untuk melakukan social mapping (pemetaan sosial) berbasis nama dalam alamat untuk mengungkapkan potensi sosial, termasuk nilai, norma, adat istiadat dan potensi sumber daya alam; informan bersedia terlibat aktif dalam desiminasi potensi kepada para pihak terkait; terdapat informan yang bersedia menjadi pendamping desa wisata ${ }_{i}$ informan juga bersedia kehadiran fasilitator desa wisata yang bisa berasal dari luar desa jika belum ada fasilitator dari dalam desa; informan bersedia memetakan kebutuhan desa wisata secara partisipatif; informan bersedia melibatkan diri dalam merencanakan, mengimplementasikan dan mengawasi pelaksaan desa wisata berbasis masyarakat berkelanjutan; informan bersedia terlibat dan mendukung komunitas desa wisata berbasis masyarakat berkelanjutan; dan informan bersedia membangun jaringan secara bersama-sama untuk membuka akses kepada publik tentang daya tarik dan pesona Pantai Panrangluhung yang merupakan bagian dari Desa Bira Desa sebagai Desa Wisata Berbasis Masyarakat Berkelanjutan (A Agustang, 2007). 


\section{Potensi dan Peluang Desa Bira Menjadi DWBMB}

Tedapat tiga konsep utama dalam pembahasan ini, yaitu; konsep desa wisata (rural tourism), konsep Community Based Tourism (CBT) dan konsep pariwisata berkelanjutan (sustainable tourism). Konsep rural tourism atau desa wisata meliputi dukungan potensi wilayah (lingkungan alam desa), kehidupan masyarakat desa, aktifitas masyarakat desa, peninggalan budaya dan tradisi masyarakat desa yang saling terintegrasi antara satu dengan lainnya (Akkus, Cetin and Akkus, Gulizar (ed.), 2018). Sedangkan menurut Peraturan Menteri Kebudayaan dan Pariwisata tahun 2010, Desa Wisata adalah suatu bentuk integrasi antara atraksi, akomodasi dan fasilitas pendukung yang disajikan dalam suatu struktur kehidupan masyarakat yang menyatu dengan tata cara dan tradisi yang berlaku.

Konsep CBT adalah model pariwisata kerakyatan yang dalam hal ini didefinisikan sebagai model pariwisata yang mengintegrasikan antara kebijakan pariwisata nasional, provinsi dan daerah, yang memberi akses seluasnya kepada masyarakat dalam hal kepemilikan, pengelolaan segala potensi dan objek pariwisata serta kontrol segala proses terkait kepariwisataan untuk kehidupan masyarakat yang berkelanjutan. Hal ini menegaskan bahwa para pihak pemangku kepentingan (stakholders) CBT, yaitu setiap individu, kelompok, atau organisasi yang dapat mempengaruhi atau dapat dipengaruhi oleh keberadaan CBT tersebut (Arifin dan Arifin, 2020). Adapun prinsip-prinsip CBT ASEAN (2016) yaitu: melibatkan dan memberdayakan masyarakat untuk memastikan kepemilikan dan manajemen yang transparan; membangun kemitraan dengan pemangku kepentingan yang relevan; mendapatkan pengakuan yang diakui oleh pihak berwenang yang relevan; meningkatkan kesejahteraan sosial dan pemeliharaan martabat manusia; termasuk mekanisme pembagian manfaat yang adil dan transparan; meningkatkan hubungan dengan ekonomi lokal dan regional; menghormati budaya dan tradisi lokal; mendukung konservasi sumber daya alam; neningkatkan kualitas pengalaman pengunjung dengan memperkuat interaksi tuan rumah dan tamu yang lebih menyenangkan; dan betujuan untuk mencapai kemandirian keuangan.

Konsep pariwisata berkelanjutan sebagaimana disetujui organisasi pariwisata dunia bahwa pengembangan pariwisata berkelanjutan membutuhkan partisipasi informasi dari semua pemangku kepentingan yang relevan, serta kepemimpinan politik yang kuat untuk memastikan partisipasi luas dan pembangunan konsensus. Mencapai berkelanjutan pariwisata adalah proses yang berkelanjutan dan membutuhkan pemantauan dampak yang konstan, memperkenalkan tindakan pencegahan dan atau korektif yang diperlukan (Asker, 2010). Prinsip-prinsip pariwisata berkelanjutan menurut Asker (2010), yaitu: memanfaatkan sumber daya lingkungan yang merupakan elemen kunci secara optimal pengembangan pariwisata, menjaga proses ekologi adalah hal penting dan membantu melestarikan warisan alam dan keanekaragaman hayati; menghormati keaslian sosio-budaya komunitas tuan rumah, melestarikan binaan mereka dan warisan budaya dan nilai-nilai tradisional, dan memberikan kontribusi antar budaya untuk saling memberi pemahaman dan toleransi; 
memastikan operasi ekonomi yang layak dan berjangka panjang, memberikan manfaat sosio-ekonomi kepada semua pemangku kepentingan yang tersebar secara adil, termasuk pekerjaan yang stabil dan pendapatan yang diperoleh peluang dan layanan sosial untuk komunitas tuan rumah, dan berkontribusi pengentasan kemiskinan; dan mempertahankan tingkat kepuasan wisatawan yang tinggi dan memastikan pengalaman yang berarti bagi para wisatawan, meningkatkan kesadaran mereka tentang masalah keberlanjutan dan mempromosikan praktik pariwisata berkelanjutan di antara mereka.

Berdasarkan data, Pantai Panrangluhung memliki potensi wilayah (lingkungan alam bahari dan pantai pasir putih), kehidupan masyarakat sosial budaya, aktifitas masyarakat desa sebagai nelayan dan sebagian pembuat perahu, peninggalan budaya dan tradisi masyarakat desa yang saling terintegrasi antara satu dengan lainnya. Hal ini dibuktikan dengan akses menuju Pantai Panrangluhung yang sudah terkoneksi dengan Pantai Bira. Meskipun masih membutuhkan perbaikan-perbaikan. Berdasarkan indikator ini maka Pantai Panrangluhung, memenuhi syarat sebagai miniatur desa wisata, dimana objek ini merupakan bagian dari Desa Bira.

Sementara itu, berbasarkan konsep CBT, informan mengaku bersedia menjadikan rumah mereka sebagai tempat penginapan bagi tamu. Hal ini menunjukkan bahwa masyarakat setempat bersedia menjadi pemilik dan melibatkan diri dalam aktifitas desa wisata tersebut selama tindak bertentang dan nilai, norma dan agama masyarakat setempat. Selain itu, informan juga bersedia bekerja sama dengan pihak dari luar dan pemerintah. Dalam konteks legalatias informan dari unsur pemerintahan bersedia memberi dukungan sebagai model desa wisata berbasis masyarakat berkelanjutan. Informan juga bersedia meningkatkan hubungan dengan ekonomi lokal dan regional. Informan mengaku menghormati budaya dan tradisi mereka. Informan bersedia mendukung konservasi sumber daya alam. Modal sosial berupa tata kesopanan dan keramahan kepada tamu yang dimiliki masyarakat di sekitar Pantai Panrangluhung menjadi pendukung dalam meningkatkan kualitas pengalaman pengunjung. Yang tidak kalah pentingnya adalah informan bersedia membuat perjanjian bersama untuk memperoleh keuntungan dari setiap kunjungan tamu dengan biaya yang terjangkau agar mereka dapat memiliki sumber penghasilan alternatif untuk mencapai kemandirian keuangan.

Demikian halnya dengan penerapan konsep-konsep pariwisata berkelanjutan, informan informan mengemukakan bahwa mereka bersedia menerapkan prinsipprinsip kehidupan berkelanjutan sebagai syarat utama pariwisata berkelanjutan. Meski demikian, informan mengaku penting untuk melakukan pendidikan bersama untuk mempraktekkan prinsip-prinsip tersebut.

Deskripsi di atas menekankan bahwa penelitian ini melengkapi konsep desa wsiata menurut Akkus and Akkus (2018) tentang pentingnya kesediaan masyarakat setempat untuk menjadikan daerah mereka sebagai desa wisata berbasis masyarakat yang berkelanjutan.

Berdasarkan uraian di atas dapat dipertegas bahwa Desa Bira, khususnya 
masyarakat di sekitar Pantai Panrangluhung, berptensi menjadi model percontohan Desa Wisata Berbasis Masyarakat Berkelanjutan. Secara konseptual, penelitian ini menemukan integrasi konsep; desa wisata, CBT, dan pariwisata berkelanjutan menjadi Desa Wisata Berbasis Masyarakat Berkelanjutan (DWBMB). Implementasi praktekpraktek keberdayaan bersama masyarakat setempat harus dilakukan secara partisipatif, pelibatan penuh untuk berbagi pengalaman, pengetahuan, keterampilan, keterbukaan akses terhadap kepemilikan dan pengelolaan sumber daya secara adil dengan mengedepankan kelangsungan ekologi. Praktek-praktek tersebut dilakukan bersama-sama dan saling mendukung antara masyarakat setempat dengan pemerintahan desa serta pemerintahan di atasnya. Selain itu, para pihak (stakeholders) bersama-sama membangun jaringan dan kemitraan yang saling menguntungkan untuk mendukung peningkatan pendapatan sekonomi keluarga.

\section{KESIMPULAN}

Penelitian ini mengeritik model pemberdayaan yang selama ini berlangsung di Desa Bira dan menawarkan model keberdayaan. Data menunjukkan bahwa model keberdayaan masyarakat dapat diimplementasikan di desa ini untuk mendukung terwujudkan Desa Bira sebagai Desa Wisata Berbasis Masyarakat Berkelanjutan (SRCBT). Dengan demikian, keberadaan Desa Bira sebagai Desa Wisata Berbasis Masyarakat Berkelanjutan diharapkan mampu meningkatkan kesejahteraan masyarakat setempat sebagaimana tujuan pariwisata. Konsep ini menekankan urgensi pendayagunaan potensi sumber daya sosial dan sumber daya alam setempat. Potensi tersebut didukung oleh adanya potensi sumber daya sosial, budaya dan ekonomi berupa; nilai, tradisi dan sumber daya ekonomi masyarakat setempat; adanya keterbukaan dan komitmen pemerintah desa untuk mendukung desa; dan keterbukaan informasi sebagai pasar produk Desa Bira. Berdasarkan hal tersebut maka dapat dipertegas bahwa temuan baru penelitian ini adalah determinasi ulang konsep pemberdayaan menjadi konsep keberdayaan. Temuan baru lainnya adalah integrasi konsep desa wisata, pariwisata berbasis masyarakat dan pariwisata berkelanjutan menjadi Desa Wisata Berbasis Masyarakat Berkelanjutan (Sustainable Rural Community Based Tourism). Penelitian ini juga melengkapi konsep desa wsiata menurut Akkus and Akkus (2018) tentang pentingnya kesediaan masyarakat setempat untuk menjadikan daerah mereka sebagai desa wisata berbasis masyarakat yang berkelanjutan. Karena jika masyarakat desa tidak bersedia maka potensi lainnya tidak dapat bermanfaat untuk mendukung desa wisata tersebut.

\section{DAFTAR PUSTAKA}

Agustang, A. (2007). Entaskan Kemiskinan: Analisis Kinerja Pembangunan Indonesia. In http://pustaka.unm.ac.id/opac/detail-opac?id=44043 1, 161 - ISBN (Vol. 2147483647). Indobis Publisher. https://scholar.google.com/citations?view_op=view_citation\&hl $=$ en\&user $=$ el8Hz IOAAAAJ\&pagesize $=100 \&$ citation_for_view $=$ el8HzIOAAAAJ:pSOncopqnHgC Agustang, Andi. (2011). Pendekatan Penelitian Kualitatif dan Kuantitatif Suatu 
Tinjauan Kritis. In Makassar: Andira Publisher. Andira Publisher.

Agustang, Andi. (2021). Filosofi Research Dalam Upaya Pengembangan Ilmu. OSF Preprints.

Andi Agustang. (2015). Dasar-Dasar Filsafat Penelitian Untuk Pengembangan Ilmu (I. I. Idrus (ed.); pertama). CV Multi Global.

Rajab, M. A., Oruh, S., \& Agustang, A. (2021). Persepsi Masyarakat Lokal terhadap Ekowisata Mangrove Kuri Caddi Desa Nisombalia Kabupaten Maros. Pepatudzu: Media Pendidikan Dan Sosial Kemasyarakatan, 17(2), 166-172.

Akkus, Cetin and Akkus, Gulizar (ed.). 2018. Selected Studies on Rural Tourism and Development. Newcastle, UK: Cambridge Scholars Publishing.

Arifin, Ansar dan Arifin, Mimi. 2020. Strategi Perencanaan Pembangunan Pariwisata Kerakyatan: Refleksi terhadap Masterplan Perencanaan Pembangunan Pariwisata Sulawesi Barat dan Wakatobi Sulawesi Tenggara. Makassar: PT. Maupa Masagena Media Kreasindo.

The ASEAN Secretariat. 2016. ASEAN Community Based Tourism Standard. Jakarta: ASEAN.

Asker, Sally et.al. 2010. Effective Community Based Tourism: A Best Practice Manual APEC Tourism Working Group. Sydney, Australia. Sustainable Tourism Cooperative Research Centre.

BPS. 2021. Kabupaten Bulukumba dalam Angka. Bulukumba: BPS Bulukumba. 2020. Kecamatan Bonto Bahari Dalam Angka. Bulukumba: BPS Bulukumba.

Ife, Jim dan Tesoriero, Frank. 2008. Alternatif Pengembangan Masyarakat di Era Globalisasi: Community Development. Yogyakarta: Pustaka Pelajar.

Musawantoro, Muhammad dan Ridwan, Masri. 2019. Potensi Pantai Panrangluhung di Bira Kabupaten Bulukumba sebagai Destinasi Wisata. Jurnal Kepariwisataan: Destinasi, Hospitalitas dan Perjalanan, Volume 3 Nomor 1, 2019. DOI: 10.34013/jk.v3i1.27.

Veeger, K.J. 1986. Realitas Sosial Refleksi Filsafat Sosial atas Hubungan IndividuMasyarakat dalam Cakrawala Sejarah Sosiologi. Jakarta: PT. Gramedia.

http://www.desabira.com/beranda/. Diakses pada 23 April 2021.

https://www.bps.go.id/indikator/indikator/view_data/0000/data/1234 /sdgs

Oruh, S. (2022, January 4). STRATEGI PENGEMBANGAN SUMBER DAYA MASYARAKAT $\begin{array}{lllll}\text { KEPULAUAN YANG UNGGUL MENUJU SOCIETY } & 5.0 .\end{array}$ https://doi.org/10.17605/OSF.IO/SP42D

Oruh, S. (2022, January 4). Supplemental materials for preprint: KAU MAU KEMANA (Refleksi Sosiologis terhadap Integritas Upaya Kesehatan Jiwa). https://doi.org/10.17605/OSF.IO/CP39Z

Oruh, S., \& Agustang, A. (2022, January 4). KESEJAHTERAAN PSIKOLOGIS (Studi Pada Dewasa Madya yang Belum Menikah di Kota Makassar). https://doi.org/10.17605/OSF.IO/ZUSKV

Oruh, S., \& Agustang, A. (2022, January 4). PENGARUH PENGETAHUAN KELUARGA, STIGMA MASYARAKAT DAN KEPATUHAN MINUM OBAT TERHADAP KEKAMBUHAN PENYAKIT GANGGUAN JIWA DI KOTA MAKASSAR. https://doi.org/10.17605/OSF.IO/K4VMP 